\title{
Spiritual gifts for biblical church growth
}

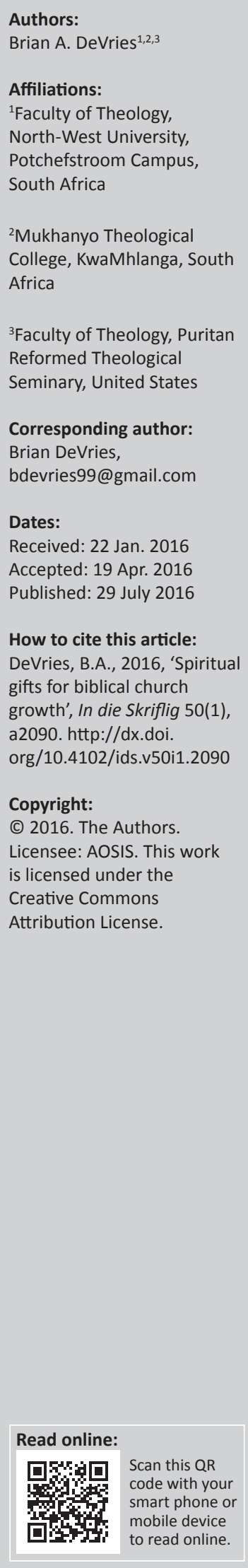

This article examines the use of spiritual gifts for church growth, particularly in relation to the sovereign work of the Holy Spirit. The article begins with a definition of spiritual gifts and by highlighting their purpose for growing the church. This is followed by two practical considerations: How should Christian believers use spiritual gifts for church growth, and how should church leaders motivate gift use for this purpose? Since the Holy Spirit works though believers to build up the body of Christ, advocates of biblical church growth should seek to employ his means to motivate spiritual giftedness in the church.

\section{Introduction}

Since the outpouring of the Holy Spirit at Pentecost, church growth ${ }^{1}$ in its various forms has always been a central focus of Christian mission. For example most histories of missions will highlight various cycles of church planting (see Isichei 1995; Shaw 1996) and church renewal ${ }^{2}$ movements during the last two millennia. Specific methods for church growth have been promoted in the church growth movement of the last century. ${ }^{3}$ More recently, church growth has received attention with the growing interest in church revitalisation. ${ }^{4}$

The presence and practice of spiritual gifts ${ }^{5}$ in the church has also been with us at least since the outpouring of the Holy Spirit at Pentecost. The 1st century church in Corinth attests to this reality, as is clear from Paul's cautions in 1 Corinthians 12-14. Also clear from these chapters and from church history is the fact that this topic has often been the subject of theological debate. While much of the modern literature has focused on definitions and the biblical use of these gifts, ${ }^{6}$ the reality of their presence in the church and mission - at least to some extent - and their importance for Christian believers cannot be debated.

How are spiritual gifts to be used for biblical church growth? The intersection of these two missional concepts - church growth and spiritual gifts - is an area of practical importance for all church leaders, even though this combined subject area has received less than adequate academic attention. ${ }^{7}$ Recent popular media has given more attention to the use of spiritual gifts for church growth. ${ }^{8}$ For example in his book, Your spiritual gifts can help your church grow, C. Peter Wagner (1979) gives practical instruction on 'discovering' your own 'unique God-given gifts' and how to use them 'to build God's kingdom'. Wagner (1979) begins his book with these words:

A relatively new thing happened to the Church of Jesus Christ in America around the 1970s. The third Person of the Trinity came into His own, so to speak. Yes, the Holy Spirit has always been there ... But rarely, if ever, in the history of the Church has such widespread interest in moving beyond creeds and theologies to a personal experience of the Holy Spirit in everyday life swept over the people of God to the degree that we are now seeing. One of the most prominent facets of this new experience is the rediscovery of spiritual gifts. (p. 19)

While many will find fault with this questionable assertion as well as the underlying teachings of his entire book, Wagner does point us in a helpful direction regarding the biblical use of spiritual 1.The term church growth is used in this article as a category label including various forms of church planting, church renewal, church
development, church revitalisation, et cetera.

2.The classic example of church renewal is the European Reformation. See also Snyder (1989).

3.For a concise review, see Anderson (2000:196-197).

4.Several of the more helpful books include Miller (1986), Reeder III and Swavely (2004), and Ross (2006).

5.By the technical term spiritual gifts, we mean the charismata and similar Greek words used in Romans 12:6-6, 1 Corinthians 12:8-10, 28-30, Ephesians 4:11, 1 Peter 4:11 and related passages. Further definition of this term and related concepts will follow.

6.For a concise review, see Satyavrata (2000:391-393).

7.Several studies with helpful chapters on this subject include Bridge and Phypers (2002), Carson (1987), and Packer (2005). For a different perspective, see Moltmann (1993:289-336).

8.For example google spiritual gifts and church growth or see the contribution from a student of John Wimber: (Pytches 1987) 
gifts for church growth, namely the person and work of the Holy Spirit who is vital for a proper understanding of both concepts.

The work of the Holy Spirit through believers in Christ's church on earth is not new at all, and it did not originate in America several decades ago. It is true, however, that less attention has been given to the focused subject area of the Spirit's work through spiritually-gifted believers in the church for the development and growth of Christ's body. This is likely due, in part, to confused teaching about the Holy Spirit and spiritual gifts, highlighted in the recent decades of debate about spiritual gifts, ${ }^{9}$ and seen more recently in the error of Pneumatological inclusivism (cf. Pinnock 1996; Yong 2005). Perhaps this lack of proper attention is also due to a greater attention in the past by Protestant Pneumatology on the work of the Spirit within each believer for regeneration and sanctification rather than through each believer in the church. ${ }^{10}$ For example John Owen, a leading theologian of the Holy Spirit among the Puritans, gives little attention to the spiritual gifts at work through lay believers in the church. ${ }^{11}$

Whatever the reasons for this lack of attention, however, there is need for greater attention to biblical teaching about the Person and work of the Holy Spirit, especially as we seek to fully understand how spiritual gifts should be used for church growth. Just as sound Christology and biblical ecclesiology are necessary foundations for the proper use of spiritual gifts in the church, a biblical understanding of Pneumatology is equally important to accurately understand and apply what the Bible teaches about spiritual gifts.

The purpose of this article therefore is to study the use of spiritual gifts for church growth, particularly on the foundation of the Holy Spirit's sovereign work. Hence the subtitle highlights the undergirding theme: the Spirit working though believers to build up the body of Christ. We will approach our subject within the structure of the following four heading questions, intentionally leading us from biblical study to practical application.

\section{What are spiritual gifts according to the Bible?}

The term spiritual gifts is not used in the Bible within its original languages, though the concept represented by the English phrase is found primarily in four passages, viz. Romans 12:3-8, 1 Corinthians 12-14, Ephesians 4:7-16, and

9.For examples of various views, see Deere (1993), Fee (1994), and Grudem (1996; 2000). For an interesting challenge to the typical reformed view of Warfield and others, see Smith (2001:39-63)

10.For excellent studies of the Spirit's internal work, see Goodwin (1979), Owen (2004), and Vaughan (1975).

11.The only full-scale treatment of spiritual gifts by any major Puritan writer is John Owen in his book, Discourse of spiritual gifts. As Packer(1990) notes: Puritan Owen in his book, Discourse of spiritual gifts. As Packer(1990) notes: Puritan ministry, and hence in those was dominated by their interest in the ordained mictery, and hence in those particular gifts which qualify a man for ministeri office, and questions about other gifts to other persons were rarely raised. .. modern questions about laymen's gifts and service were given less of an airing than we might have expected of hoped for (p. 219).
1 Peter 4:10-12. We find in the New Testament a number of uses of the Greek word charisma, meaning gift of grace, and also the Greek word pneumatik, meaning of the spirit or spiritual. The clearest passage which uses both of these terms is 1 Corinthians 12, particularly verses $1-11$. In this chapter the Apostle Paul teaches about 'spiritual things' particularly in relation to the 'varieties of gifts' that are given to believers for the building up of Christ's body, the church of God. Thus the English term spiritual gifts and the corresponding theological concept is best understood by a study of these passages within their 1 st century context. ${ }^{12}$

Each of the four passages on spiritual gifts makes a list of gifts or ministry abilities from God for service in the church. None of the lists includes all gifts; each of the lists provides a sampling of the ways that God equips and empowers believers for ministry in the church. ${ }^{13}$ These gift lists have been classified in several different ways: some divide them into gifts of speech and gifts of Samaritanship (Packer 2005:70-71); others in gifts of service, utterance (speaking), and miracles (Satyavrata 2000:391-393); others into the ordinary (which continue) and extraordinary (which have ceased); and still others into gifts of prophetic, priestly, and kingly (leadership) service (Poythress 1996:71-101). This is not the place, however, for an extended discussion about the socio-historic contexts of these passages or how to best classify the various gifts of grace. Our purpose in this article is rather to present a simple biblical definition of these spiritual gifts so we can explore practical ways how they should be used to build the church.

\section{Spiritual gifts defined}

How should we explain the theological concept of spiritual gifts? These gifts of grace from God are to be understood as the equipping and empowerment of the believing followers of Christ by the Holy Spirit, so that they can participate in building up the body of Christ. Spiritual gifts are capacities of believers to express and communicate the knowledge and power of Christ for the purpose of edifying the church (Packer 2005:145). Every believer in the body of Christ is 'empowered by one and the same Spirit, who apportions to each one individually as He wills' (1 Cor 12:11).

Popular uses of the term spiritual gifts tend to focus on the possession of a tangible gift by an individual or an acquired ability of a person to perform certain functions. But the several gift-passages listed above, together with other biblical instruction (e.g. 1 Cor 2:1-5, 10-16; 2 Cor 3:4-6) highlight the source of these capacities. They come from the triune Giver (cf. Rm 12:3; 1 Cor 12:4-6), and particularly from the Holy Spirit who empowers believers for ministry in the church. It is the presence of the Holy Spirit in believers' lives that empower them to minister in various ways and make them 12.For a thorough exegetical study, see Berding (2000:37-51).

13.For a useful quick reference chart, see http://www.esvbible.org/resources/esvsb/ chart-45-04/ 
effective in ministry, so that the church is edified. This spiritual-giftedness is not produced by the natural abilities and talents that a person possesses to varying degrees, but rather the 'demonstration of the Spirit and of power' who is actively working in and through the believer for the edification of Christ's body.

Consider, for example the spiritual gift of preaching. ${ }^{14}$ How should we define genuine spiritual giftedness in preaching? We could focus on the exegetical and homiletical abilities of the preacher to understand and apply God's Word in a particular context. We could give attention to his communication or pedagogical skills, such as his rhetoric and wisdom. But while all of these abilities and skills have value, the ultimate spiritual success of preaching lies 'not in plausible words of wisdom, but in the demonstration of the Spirit and of power' so that the faith of the audience 'might not rest in the wisdom of men but in the power of God' (1 Cor 2:1-5). As the Apostle Paul reminded the Thessalonians, 'our gospel came to you not only in word, but also in power and in the Holy Spirit and with full conviction' (1 Th 1:5a). Thus the spiritual gift of preaching should be defined, not as exegetical and homiletical abilities or as communication and pedagogical skills, but rather as the presence and power of the Spirit working in and through the preacher as a believing person (who may also have natural abilities and acquired skills) in order to produce spiritual results in those who hear, as sovereignly desired by the Spirit. ${ }^{15}$ Likewise, as the Holy Spirit works through a preacher with the gift of preaching, the Spirit also works in and through each believer with the particular spiritual gifts they have been given (cf. 1 Jn 2:20, 27).

\section{Trinitarian source of gifts}

Spiritual gifts must also be understood as coming from the triune God (1 Cor 12:4-6). All three Persons of the Trinity are actively involved in spiritually gifting each believer for ministry in the church.

God the Spirit empowers all believers with a variety of different abilities but all by the same method of powerfully working within and through them. Thus it is not correct to speak of these spiritual gifts as natural abilities that are possessed by individuals, as if the Holy Spirit is a physical object like a tool, a mechanical energy like electricity, or a metaphysical power like magic and muti. The gifts cannot be separated from the Giver. Rather these spiritual gifts are enabling abilities and spiritual competence (cf. 2 Cor 3:4-6) that are a direct result of the Spirit's personal abiding presence (Rm 8:9-10) and his occasional special filling for a particular ministry (Ac 4:31).

14.This gift has been called by many names: unction, anointing, or the gift of prophecy. If prophecy is defined as the Spirit-empowered authoritative communication of God's Word, then we should consider preaching to be the activity of those who have been given the spiritual gift of prophecy (Rm 12:6; 1 Cor 12:10). The Puritans defined preaching in this way; cf. Perkins (1996).

15.For one of the best explanations of the spiritual gift of preaching that accurately highlights the role of the Holy Spirit, see Marcel (1963).
God the Son is the sovereign owner of all spiritual gifts. Christ has merited these gifts for his church. In Ephesians 4:7-11 the Apostle Paul explains how the gifts of grace, received by each believer individually are given by the victorious Christ, flowing from his finished work of redemption when he ascended to the highest place of power. As the victorious Savior-King, Christ has given and is distributing these gifts in his church by his Spirit (1 Pt 1:1012). This distribution of gracious gifts is performed in part through the spiritual leaders he has appointed in his church, who in turn are equipping all believers for ministry in order to build up the body. Through these leaders, and as elsewhere presented, by the direct presence and power of the Holy Spirit, Christ is governing all spiritual gifts within his church. So all spiritual gift use is an extension of Christ's ministry in the church; hence they must function in the church exclusively under his authority. ${ }^{16}$

God the Father is the sovereign Giver who makes each gift effective. Packer (2005) is helpful on this point:

Some natural abilities that God has given he never uses [to edify], while sometimes he edifies through performances that to competent judges seem substandard. This is characteristic: God highlights the weaknesses of those whom he saves and uses, so that nothing will rival or obscure his glory (1 Cor 1:27-29; 2 Cor 4:7; see also 12:9). When, therefore, Christians are said to 'have gifts' (Rom 12:6), the meaning is not that they are in any respect outstandingly brilliant or efficient (they may be, they may not; it varies), but rather that God has observably used them to edification in specific ways already, and this warrants the expectation that he will do the same again. We need to draw a clear distinction between man's capacity to perform and God's prerogative to bless, for it is God's use of our abilities rather than the abilities themselves that constitute charismata. (p. 71)

\section{Spiritual gifts distinguished}

Spiritual gifts, or rather spiritual giftedness, are gifts of the Holy Spirit graciously given by the triune God to equip and empower believers so that they, even with their own weaknesses, can effectively participate in the building up of the body of Christ. Before moving on to study the purpose for which they are given, we should pause to distinguish spiritual gifts from several other closely related biblical concepts.

Firstly, these gifts of the Spirit should be distinguished from the Gift of the Spirit. ${ }^{17}$ Before his crucifixion and resurrection, Jesus instructed his followers that they should wait for the Promise of the Father (Lk 24:49; Ac 1:4), which is the Holy Spirit whom he had received from God the Father and whom he would pour out into his church (Ac 2:33). This Gift of the Holy Spirit is received upon repentance and faith in the covenant promise of Christ (Ac 2:38-39). Thus every believer

16.It is for this Christological reason that Poythress classified all spiritual gifts with the tradition triad of Christ's ministry functions and offices within the church, namely prophet, priest, and king. Note the helpful discussion in Poythress (1996:71-101; 2010:11-13).

17.For an extended discussion about this distinction, see Gaffin (1979:13-41 and especially 43-45) 
immediately receives the Gift of the Holy Spirit - the same promise received by the Apostles on Pentecost - at the point of spiritual regeneration ( $\mathrm{Rm} 8: 9-10)$. But every believer at different stages and times has different measures of being filled with the Spirit (Köstenberger 1997:229-240; cf. also DeVries 2007:138-149), and every believer has been and is being given different kinds and degrees of spiritual giftedness. Thus the Gift of the Spirit received by all believers works within them to produce a variety of different spiritual gifts.

Secondly, spiritual gifts are related to but separate from the fruit of the Spirit (Gl 5:22-23) and faith-based spirituality (2 Pt 1:5-12). Scripture is clear about these different facets of the Spirit's ministry in and through believers. It must be noted, however, that it is highly unlikely that spiritual giftedness will be evident in a person's life when there is no evidence of spiritual fruit and genuine spirituality. If a person without spiritual fruit claims to have spiritual gifts, it is very likely that these so-called spiritual gifts are instead counterfeits or misconceptions, since the Holy Spirit never does a half-done work but usually first begins to transform believers before using them in ministry (cf. 1 Cor 12:2-3). Should such be the case, it is more likely that the person is spiritually dead and only being used by God to accomplish his sovereign purposes in the same way that God used the wicked Assyrians in the Old Testament to punish his disobedient people.

Thirdly, these spiritually-gifted ministry abilities are not identical with spiritual authority and spiritual leadership within the church. Spiritual leadership in the church is an official responsibility that God has sovereignly chosen to place upon men. ${ }^{18}$ But all believers - both male and female are spiritually-gifted for various kinds of ministry functions (cf. Jl 2:28). Though women also are spiritually-gifted for various ministries within the church and are empowered by the Holy Spirit to build up the church, Scripture does not permit them to 'exercise authority over a man' (1 Tm 2:8-15; 1 Cor 14:33-35). Hence Scripture implies a distinction between the responsibility of leadership office and the spiritual giftedness for ministry functions. ${ }^{19}$

\section{Why are spiritual gifts given to believers in Christ's body?}

The Holy Spirit empowers believers with spiritual giftedness in order to build up the body of Christ. This goal, in short, is the purpose for which the triune God has given and is distributing spiritual gifts. It is helpful to unpack this concise answer, since by doing so we will be able to develop a multifaceted understanding of how to encourage the use of spiritual gifts for biblical church growth in our own contexts and ministries.

18.For a thorough exegetical study to support this assertion, see Piper and Grudem (1991).

19.There is much discussion about this third distinction. For further insight, see Gaffin (1979:50-51).

\section{Exegetical study of purpose}

Two New Testament passages need careful attention in order to understand God's intended purpose and our proper use of spiritual gifts. The most complete biblical teaching on spiritual gifts is 1 Corinthians $12-14$.

Take note of several exegetical points, firstly from chapter 12 . Verses 4-6 give both a trinitarian understanding of spiritual gifts - as reviewed above - and also three words showing progression from giftedness to functionality to practical activity:

Now there are varieties of gifts [charisma], but the same Spirit; and there are varieties of service [diakonia; ministries], but the same Lord; and there are varieties of activities [workings], but it is the same God who empowers them all in everyone.

Different spiritual gifts are given by the Spirit for different ministry functions, which are used for different activities in the church. Verse 7 explains the reason the Spirit's presence and work is made known in the spiritual gifts of believers: 'To each is given the manifestation of the Spirit for the common good'. Verse 25 implies another reason why a diversity of spiritual gifts is given and how they should be properly used in the body: 'that there may be no division in the body, but that the members may have the same care for one another'. The Spirit has gifted each member of the body in different ways so that the holistic use of these gifts will function in unity to provide mutual care to all members (Carson 1987:4950).

Chapter 14 suggests additional points to consider. Verses 1-6 compare the result of the less valuable gift of tongues building up oneself - with the more desirable and valuable gift of prophecy, which is for building up the church: 'The one who speaks in a tongue builds up himself, but the one who prophesies builds up the church'. Thus the value and desirability of a spiritually-gifted ministry is judged by how effectively it builds up the church. Verses 7-12 present an example to affirm this teaching. Then verse 19 makes a strong assertion about how to evaluate giftedness: 'Nevertheless, in church I would rather speak five words with my mind in order to instruct others, than ten thousand words in a tongue'. There is a radical difference between a spiritually-gifted ministry that builds up compared with a personal giftedness that has limited value to the whole church. Thus spiritual gifts, while perhaps useful in private settings, are primarily to be used for building up the church (Carson 1987:101-103). Note the focus is not on the individual believer who has been gifted, but rather on the purpose and result of the gift within the church. The rest of this chapter, which will be examined in part below, expands on this teaching and concludes with a summary statement.

The second passage with clear instruction on the use of spiritual gifts is Ephesians 4:11-16. Admittedly this passage is more Christological with few direct references to the Holy Spirit. It must be understood, however, within the context of the Christian life that flows from the spiritual blessings of 
Christ (Eph 1:3ff.) and the indwelling of Christ's Spirit (Eph $1: 13-14 ; 2: 20-22)$ for the new life of obedience (Eph 4:1ff.; 5:1-2) that does not grieve the Spirit (Eph 4:30) but rather is characterised by being filled with the Spirit (Eph 5:18).

Within this context Ephesians 4:11-16 explains that the gift of Christ's grace is distributed, particularly - in this passage through officially appointed church leaders, in order to equip the saints (i.e. all believers united with Christ) for two ${ }^{20}$ interrelated activates: 'for the work of the ministry' and 'for building up the body of Christ'. Thus each believer has to cooperate in mutual ministry for growth of the whole body, just as all the parts and ligaments of the human body work together properly for healthy growth and maturity. The goal in view is a mature spiritual body, which Paul compares by analogy with 'the statute of the fullness of Christ', the new multi-ethnic humanity in Christ (Eph 2:15). In so doing this spiritual body of Christ - the church of believers - will avoid being distracted by false teaching and deceitful schemes, thus demonstrating they are no longer spiritual children but mature spiritual members of Christ's spiritual body.

Why then are spiritual gifts given to believers in Christ's body? They are given for ministry functions and lead to practical activities within the church. They are given for the common good of all believers. They are given to promote unity, and so that all members will mutually care for each other. They are given to build up the church, the body of Christ. They are given to equip all believers for the everymember ministry to which they have been called, so that they together with all believers everywhere and in all times can participate in building up the new multi-ethnic humanity in Christ.

\section{Discernment and further distinctions}

Since there is much questionable teaching concerning spiritual gifts today, as there was in Paul's day, we need to briefly consider several notes of discernment. This will be followed by a discussion of categorical distinctions among the spiritual gifts God has given, so that, as Paul cautions, we are not uninformed (1 Cor 12:1) or tossed about by devious distractions (Eph 4:14).

Firstly, the Bible does not teach that evidence of spiritual giftedness in a believer's life is an indication or proof of a higher level of Christianity. All believers, regardless of their present state of spiritual obedience, are members of the body of Christ, and all believers have received the Gift of the Holy Spirit. So all genuine believers will have a faith-based

20.The KJV gives an unfortunate English translation of Ephesians 4:12: 'For [pros] the perfecting of [equipping; katartismos] the saints, for [eis] the work of the ministry [service; diakonia], for [eis] the edifying of [building up; oikodoma] the body of Christ.' This translation tends to imply that the appointed church leaders have a three-fold responsibility of equipping, ministering, and edifying. In practice this translation tends to find expression in a clear distinction between the active work of church offices (i.e. the clergy) and the passivity of all believers (i.e. laity). But the Greek prepositions in this verse require a clear distinction between the equipping work of church leaders and the ministry and edification of all believers. Hence all believers, including the so-called laity, are spiritually gifted for the work of the ministry and for building up the body of Christ, and not just the clergy as is common in high-church traditions. The ESV gives a better translation, namely 'to equip the saints for the work of ministry, for building up the body of Christ'. spirituality (2 Pt 1:5-12), show the fruit of the Spirit (Gl 5:22-23), and demonstrate spiritual giftedness to some degree. Those who teach that the demonstration of a socalled extraordinary gift (i.e. speaking in tongues) is proof of a second level of blessing fail to support their assertion with biblical teaching (Grudem 1994).

Secondly, we must clearly teach and demonstrate in practice that some gifts are to be desired more than others gifts. Paul under the inspiration of the Holy Spirit wrote: 'earnestly desire the higher gifts' and 'I would rather speak five words with my mind in order to instruct others, than ten thousand words in a tongue' (1 Cor 12:31a; 14:19). Which gifts are higher and thus more to be desired? The answer is clear from the text: the better gifts are those spiritually-gifted ministries that best fulfil the purpose for which the gifts are given. We must desire to be used by God in spiritually-gifted ministries that are best able to build up the body of Christ, best suited to bear witness to the exclusive truth of Christ, best qualified to demonstrate the love of Christ to a dying world. If speaking in tongues is the best way to proclaim Christ and build up his church we should 'not forbid speaking in tongues'21 (1 Cor 14:39); but since in all cases, tangible Christ-like love and witnessing of Christ (i.e. prophecy, Rv 19:10) and gracious service to others in Christ's name are much better spiritual gifts, we should passionately desire and seek to be used by God with these higher gifts.

Thirdly, it is necessary to note several biblical distinctions among the spiritual gifts. This point of discernment and the one just mentioned above, can quickly draw us away from the focus of this article and into the complex theological debates alluded to in the introduction. So we will be brief on this point, concisely summarising a helpful study by Poythress (1996:71-101). ${ }^{22}$ There are at least two helpful distinctions to note with assistance from Poythress.

In the first place we must carefully define the authoritativeness of each gift-use. Some people in the past have been gifted by the Spirit to write Scripture, which has an enduring authority much greater than any other form of revelation today $(2 \mathrm{Pt}$ 1:16-21). But the biblical canon being now closed (Rv 22:18-19; cf. 1 Cor 14:37), we can be sure the apostolic authority evidenced in this special giftedness will not be experienced again. A similar distinction in authority, however, is still true in the church today: Some believers (e.g. pastors) are gifted to teach the word (i.e. gift of teaching) with authority in the church, their authority being derived from and equal to the degree to which they accurately communicate God's truth. While other believers (e.g. math teachers), teaching with equal ability as well as spiritual giftedness, do not have the same spiritual authority in the church, since the content taught is based on God-given human reason rather than being an accurate communication of the once-for-all inspired Word of God.

21.One should not necessarily assume, however, that the current Pentecostal practice of speaking in tongues is identical with what Paul is writing about in this chapter.

22.For a more popular version, see Poythress (2010). 
There are secondly different processes by which spiritual gift use is motivated. Some may feel led by the Spirit to use their spiritual giftedness in a specific way, while other believers may obey the commands of Scripture as a guide for their gift use. ${ }^{23}$

\section{Tests for spiritual giftedness}

With these definitions and distinctions in mind, it is now possible to outline a concise framework of spiritual gift use for the purpose of church growth. Consider briefly five criteria by which to test genuine spiritual giftedness:

- Genuine spiritual giftedness as given by God is evidenced when the Holy Spirit empowers believers so that despite their own great weaknesses, they are strong to accomplish his purposes.

- Genuine spiritual gifts are graciously given to us on account of Christ's merits and are used under the authority of the church leaders he has appointed.

- The use of spiritual gifts can never be separated from the Holy Spirit, since these gifts are not natural abilities but rather the direct result of his presence and power working through the believer.

- Genuine spiritual giftedness will always lead to church growth, evidenced in the various ways believers are mutually cared for and the church is built up.

- Spiritual giftedness will always bring greater glory to God (1 Pt 4:10-11).

If the so-called gift persons claim to possess does not produce evidence within this five-fold framework, then it may be that they are misguided and do not understand what the Bible teaches about spiritual gifts and their appointed purpose of church growth.

\section{How should believers use spiritual gifts for church growth?}

How should Christians use their spiritual giftedness for church growth? This practical question immediately raises the issue of gift identification. How can each believer in the church identify which gifts to use for the benefit of the whole body? Much popular material has been produced for identifying spiritual gifts, ${ }^{24}$ much of which is simply a modification of secular aptitude tests or personality assessments. The Bible commands us not to quench the Spirit or deny prophecies, but rather to test everything and hold fast to what is good in order to abstain from evil (1 Th 5:19-21). So discernment in this area also is both wise and necessary.

23.A classic example here is the calling to pastoral ministry: One may be called by objectively studying the Bible's teaching about spiritually-gifted requirements for this calling in comparison to the spiritual gifts evident in one's own life. Another may feel called by the subjective prompting of the Holy Spirit and the spiritual passion to witness of Christ. Both the objective study of God's Word and the subjective experience of the Spirit's prompting are necessary for a calling to pastoral ministry. Yet it is very difficult for another believer to verify the subjective aspect of this calling: the objective truth is binding for all while the subjective aspect of this calling, the objective truth is binding for all while the subjective the Word caide the Spirit prompts subjectively in a way that may or may not be binding for others.

24.Googling spiritual gifts test will yield a host of options from a wide variety of theological traditions: spiritual gifts assessment questionnaire, spiritual gifts analysis, discovery of spiritual gifts, online spiritual gifts inventory, et cetera.

\section{Identifying the Spirit's presence}

It is helpful therefore to remind ourselves again that spiritual giftedness is the direct result of the presence and filling of the Holy Spirit in a believer's life. For example the most spiritually-gifted person in the world was Jesus Christ, as publically demonstrated in the Gospels during his earthly ministry. The Holy Spirit was given to Jesus without measure, and thus he spoke the Word of God (i.e. prophesied), taught, demonstrated wisdom, healed, performed miracles, and gave many other evidences of spiritual giftedness (Jn 3:34; 1:32-33). In the same way, though to a much lesser extent, the Apostles where also filled with the Holy Spirit (as promised by Jesus) and they also demonstrated the presence and power of the Spirit in their lives 'by word and deed, by the power of signs and wonders, by the power of the Spirit of God' in their apostolic ministry (Rm 15:18-19).

How should we as believers then use our spiritual giftedness for church growth? As in Jesus' earthly ministry and the ministries of the apostles, we also need the presence and filling of the Holy Spirit. When the Spirit is present in our lives and when he has empowered us for the ministry of church growth, then he will be using our spiritual giftedness to build up the church and glorify Christ. Therefore when identifying spiritual gifts, we should give direct attention to the presence of the Holy Spirit in our lives, just as Scripture highlights how Jesus was filled with the Spirit for his earthly ministry.

It is often difficult, however, to physically observe and quantify the presence of the Spirit in our lives. Likewise, it is not possible to use an objective test to determine the subjective spiritual presence of the Spirit. We must rather look for genuine spiritual signs of his presence in one's life, as Jesus taught, 'you will recognize them by their fruits'. (Mt 7:16a, 20). This teaching in context was directly applied to false teachers and those who cast out demons, but it can also be applied by implication to test the genuineness of all believers. The Bible gives us at least two such testing criteria, viz. the fruit of the Spirit list in Galatians 5 and the spiritual qualities of godliness series in 2 Peter 1.

Rather than relying on aptitude tests or personality assessments and the like, it is much safer to encourage the use of biblical criteria to determine the presence and power of the Holy Spirit in the life of a believer. Many of the spiritual gifts tests available today appear to be better designed to identify the human talents and personal abilities. But the things of the Spirit must be spiritually discerned (1 Cor 2:14b; cf. 2:6-16), therefore we should rather use the criteria given to us in the Word inspired by the Spirit, lest we are led astray by faulty tests and a misunderstanding of the things of the Spirit.

\section{Spiritual giftedness tests}

With this caution in mind, consider the three ${ }^{25}$ prominent spiritual giftedness tests given to us in Scripture. The first criterion

25.These three sets of criteria apply to all Christian believers. There are also specialised criteria for specific ministries, such as the qualifications for the leadership offices of elders and deacons in 1 Timothy 3 and Titus 1. 
is the test of faith. The Apostle John clearly distinguishes between false spirits and the Spirit of God, between works of darkness and walking in the light, between those who are being deceived and those who are in spiritual relationship with the Truth, between false prophets and those who have been anointed by the Holy Spirit with true spiritual knowledge (1 Jn). In short, John distinguishes between unbelievers and believers. These distinctions are helpful, because unbelievers are not given spiritual gifts. Even Christians who have discovered certain so-called spiritual gifts may be deceiving themselves. John calls us all to self-examination while also pointing us to Jesus Christ in whom alone we can be blessed with faith and the Spirit's sealing assurance. Without a spiritual life of fellowship with the triune God in Christ by faith (1 Jn 1:3ff.), it is impossible to have any gifts of the Spirit.

The second criterion is the test of fruit. As noted above, the Holy Spirit never does a half-done work. He always produces both fruit and gifts at the same time. Both fruit and gifts are the direct result of the Spirit's presence, so it is impossible to have some of the one without any of the other. Thus the list of the fruit of the Spirit in Galatians 5:22-23 is a reliable set of criteria for clearly distinguishing the true from the false. If so-called Christians do not demonstrate any fruit of the Spirit in their lives, then it is pointless to try to identify their spiritual gifts. Rather the gospel message and proper teaching is required for such persons (as Paul instructed the disciples of John in Ac 19:1-7) since they are misguided and in danger of being misused or falling away. Furthermore, it can also be stated that the degree to which the fruit of the Spirit is seen in believers' lives is usually the same degree to which spiritual giftedness will be present in their lives as well, since both are the result of the presence of the same Spirit.

The third criterion is the test of godliness. The relationship between spiritual gifts and spiritual godliness (as taught in 2 Pt 1:3-15) is similar to the relationship between spiritual gifts and the fruit of the Spirit. The degree of spiritual gifts in believers' lives usually directly corresponds with the degree of spiritual godliness in their lives. Peter encourages us all to examine ourselves (2 Pt 1:5-9), since without these qualities of genuine godliness, we will be ineffective and unfruitful, and hence not demonstrate any spiritual giftedness in our ministry. Thus this set of criteria is also reliable for clearly distinguishing the true from the false.

\section{Do not be immature}

A few additional thoughts should be noted for the sake of biblical discernment. Firstly, we should take note of the Apostle Paul's tone at the beginning of his teaching in 1 Corinthians 12-14: 'I do not want you to be uninformed ...' and again later, 'Do not be immature in your thinking' (1 Cor 12:1b; 14:20). Speaking with love in the Spirit, Paul urges caution to the church in Corinth regarding the subject of spiritual gifts. ${ }^{26}$ So we must be zealous to test everything with the Word of God and to hold fast only to what is good (1 Th 5:21).

26.And if they needed caution in Paul's day, then certainly we need to hear these cautions today. The radically conflicting ideas about spiritual gifts in the church
today, together with misguided definitions and unbiblical practices are causing today, together with misguided definitions and unbiblical practices are causing many, I fear, to quench the genuine Spirit of God and to grieve him greatly.
Secondly, we must constantly remember that unlike personal abilities and talents, spiritual gifts are not a material thing or skill we have; nor are they our own perceived strengths and abilities. Rather spiritual giftedness is an indication of what God the Holy Spirit is doing through us, even at times in spite of ourselves and our weaknesses (2 Cor 12:9). Like Samson's Spirit-given superhuman strength, the spiritual giftedness we might experience for church growth will quickly disappear as soon as the Spirit of God is grieved by our disobedience and no longer chooses to fill us with his power as before. So the method to determine our spiritual gifts is not to ask: What is my spiritually thing that sets me apart from other believers? Rather the better question to ask is: What in the situation in which God has placed me are the particular opportunities I see for serving other believers in Word and deed (cf. $1 \mathrm{Pt}$ 4:10ff.)? 'What are the specific needs confronting me that should be ministered to?' (Gaffin 1979:53)

Thirdly, sober faith-based judgement requires that we assess our own spiritual giftedness with humility. ${ }^{27}$ A self-focused self-assessment of one's personal abilities and successes - as can be encouraged by the popular gift tests - has the dangerous tendency to promote judgement of oneself that is based on the quantifiable amount of good works performed, causing them to 'measure themselves by one another and compare themselves with one another', which is spiritually unwise (2 Cor 10:12). This is not the method or attitude of Paul (cf. 2 Cor 3:4-6). Encouraging self-centered assessments of one's perceived successes does not promote humility and gift use that gives all glory to God.

\section{Guidelines for gift use}

The giftedness of the Spirit, according to the Bible, should be used in ways that are consistent with the following four principles: Firstly, spiritual giftedness is to be used for the purpose of building up the church. As already discussed above, the purpose of the Spirit's gifting of all believers is to build up the body of Christ, the new multi-ethnic humanity which is the church of God (Eph 4:7-16). Paul's instruction to the church of Corinth is the same: 'Let all things be done for building up' (1 Cor 14:26c). So it is necessary and helpful for believers to periodically examine whether they are using their giftedness for the building up of the church, both as a local body of believers, and in some cases more broadly as a regional or international collective of local churches. Practical tests for self-examination could be added here, because each situation will be different.

Secondly, spiritual giftedness is to be used in an orderly way and under biblical leadership. The Apostle Paul teaches that gift use 'should be done decently and in order' (1 Cor 14:40) since 'God is not a God of confusion but of peace' (1 Cor 14:33). These two statements summarise his instruction about how spiritual gifts - particularly the gift of tongues - should be used in the church setting. Tongue speaking in Corinth

27.Paul's warning in Romans $12: 3$ about gift assessment must not be forgotten: 'For by the grace given to me I say to everyone among you not to think of himself more
highly than he ought to think, but to think with sober judgment, each according to highly than he ought to think, but to think with
the measure of faith that God has assigned'. 
was creating a disorderly commotion. Paul therefore gives specific instructions to guide and regulate the use of this gift in the church, so that the disorderly commotion would not cause unbelievers to question the validity of what was happening (Carson 1987:117-134). Likewise the Bible also teaches that:

as in all the churches of the saints, the women should keep silent in the churches. For they are not permitted to speak, but should be in submission, as the Law also says. (1 Cor 14:33b-34)

Even though a believing woman is spiritually-gifted to speak the gospel of Christ in other situations and though she does so effectively, she is not permitted to exercise this gift in the churches in order to show submission to biblical leadership. Thus Paul is saying that giftedness must be used in the church both orderly and under biblical leadership.

Thirdly, spiritual giftedness is to be used at all times within biblical bounds. As the Apostle Paul also writes in his instruction to Corinth: 'if anyone does not recognize this, he is not [to be] recognized' (1 Cor 14:38). All use of spiritual giftedness must at all times be consistent with the Bible, which is the inspired Word of the Spirit of God. Failing to minister according to the instructions of this Word will grieve the Spirit and even quench the Spirit's effective work. It may be that misuse of ministry competence in the church may lead to measurable results, but the final day of God's testing will disclose which ministries have eternal value (1 Cor 3:10-15).

Fourthly, spiritual giftedness is to be used in faithfulness for God's glory (Rm 12:6-8). Every spiritual giftedness will produce different ministry activity that corresponds with the giftedness that is being given, and each should be used according to the measure of grace given by the Spirit (cf. 1 Cor 12:11ff.). But all spiritual gifts must be used in faithfulness with an attitude of gracious humility for the glory of God through Jesus Christ (1 Pt 4:10-11).

\section{How should leaders motivate gift use for church growth?}

The question in this final section pertains primarily to church leaders. This subject is larger than the space remaining, but we should at least consider several practical implications. We start with a few thoughts about the responsibilities of church leaders, concluding with several recommendations for developing spiritual giftedness.

\section{Growing gifts in God's garden}

It is the responsibility of church leaders to help develop the spiritual giftedness of all church members under their care so that these believers will be used by the Spirit to develop the church. Both the example of Jesus and the instruction of Paul encourage us to be faithful in this duty. Consider, for example how Jesus mentored a large number of disciples: the 11 in his inner circle, the 70 spiritually-gifted and sent out to proclaim the good news, and about 120 faithful followers on the day of Pentecost.
The Apostle Paul's teaching clearly outlines this responsibility of church leaders. The risen Christ appointed leaders in the church for the purpose of equipping the saints for ministry and church growth (Eph 4:11-12 as explained above). Paul is also an example of how experienced church leaders should encourage other believers to greater gift-use. As Paul instructed Timothy to not neglect but rather to grow and develop in his spiritual giftedness (1 Tm 4:14; 2 Tm 1:6), we as church leaders also need to instruct and encourage believers to do the same.

Church leaders should pray for the spontaneous use of spiritual giftedness within the body even while they work to create a climate for spiritual growth. This is implied by Paul's agricultural metaphor in 1 Corinthians 3:6: 'I planted, Apollos watered, but God gave the growth'. Both he and Apollos as leaders of the church were busy with the planting and watering work in God's spiritual garden, even while they were praying for God to sovereignly produce the desired growth. Or in other words, the Holy Spirit is the One who gives spiritual gifts and sovereignly produces their growth, while church leaders are the Christ-appointed means - used by the Spirit - to accomplish his purpose of church growth.

Paul's garden metaphor can be stretched a bit to make a further point. If there is no growth in God's garden, then perhaps - and it must remain a potentiality, since God is sovereign - the climate and activity in the garden is not right for such growth. If a genuine giftedness growth and ministry of all believers is not happening spontaneously, then it is likely that there is not a proper climate for spiritual growth in the church. What then should church leaders do - as spiritual farmers in God's garden - so that the situation will change? Certainly passionate prayer for God's undeserved blessings is absolutely required. But there is also much work to do. Church leaders should not try to identify artificial gifts or highlight natural abilities as a substitute for genuine spiritual giftedness. Putting plastic plants in the garden will not produce the desired results. Rather church leaders should prayerfully work to create the proper climate for spiritual giftedness growth and use. What will this look like? It will be a church where the Holy Spirit is working within each believer so the fruit of the Spirit (Gl 5:22-23) is increasingly seen in their own lives and among them in the church. It will also be a church where the Holy Spirit is adding to each faithbased believer in the church all the qualities of spiritual godliness: virtue, knowledge, self-control, et cetera (2 Pt 1:3-15). Praying and working to produce such a climate is perhaps the most important role of leadership functions within the church.

Church leaders must also correct false motives and false teachings. To use the above metaphor again: part of creating a proper climate in the church for giftedness growth is the hard work of pulling out weeds. False motives and false teachings are like weeds that seriously stunt or even prevent genuine giftedness growth. Since many Christians are still spiritually immature they are 'tossed to and for by the waves and carried about by every wind of doctrine, by human 
cunning, by craftiness in deceitful schemes' (Eph 4:14). Church leaders and all believers therefore must speak the truth in love. They must faithfully and boldly speak against all doctrinal error and deceitful schemes. They must also lovingly correct those who still misunderstand what the Bible teaches about spiritual gifts. In this way, the church will be built up in love into the maturity of the fullness of Christ.

\section{Intentional development of gifts}

In order to experience this biblical church growth, church leaders should intentionally work to develop the spiritual giftedness of church members under their spiritual care. Though only the Spirit can produce the results we desire, church leaders must plant and water. We conclude with four recommendations for developing spiritual giftedness:

Firstly, church leaders should promote the growth of spiritual fruit (Gl 5:22-23), spirit-filled godliness (2 Pt 1:3-15), and genuine biblical spirituality in the church, which is the only sure way to increase spiritual giftedness for lasting church growth. Promoting genuine godliness and biblical spirituality is perhaps the most important ministry of church leaders. All believing members of the church should be busy with mutual member care; they should all be busy with the "work of the ministry' for building up the body. But church leaders are specifically called to equip the saints for this spiritual ministry, and the only sure method for such equipping is to promote the spiritual fruit and spirit-filled qualities evidenced in genuine biblical spirituality. ${ }^{28}$

Secondly, church leaders should preach and teach about spiritual gifts and gifted-ministries. Since there is much confusion on this subject today, an extended teaching plan should be developed by the leaders of a church to give the members a comprehensive understanding of the what, why, and how of spiritual giftedness. These truths should be consistently taught in sermons, studies, and other media so that members will be led by the Holy Spirit to use their giftedness in various ministry methods for the growth of the church. Even when there is a proper climate for giftedness growth (recommendation above), it could be that spiritual giftedness remains mostly dormant due to a lack of instruction within the church. But church leaders should not stop with these first two recommendations. They are also responsible to do much more.

Thirdly, church leaders should create space for every-member ministry (Packer 2005:153). To use the planting and watering metaphor once more, church leaders need to create climatecontrolled greenhouses for the growth of spiritual gifts. It is true that the Spirit alone is the One who gifts believers to ministry in specific situations; yet creating such situations often leads to the giftedness growth of believers which in turn leads to greater church growth. For example it might be that a particular member is being given (or will be given) the spiritual

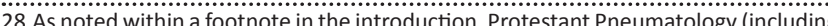
contributions from the Puritan era) has failed to produce much literature on the work of the Holy Spirit through believers in the church (i.e. spiritual giftedness). But in this area of biblical godliness and spiritually the Puritans are second to none. gift of teaching. The church leader might not even know who will be given this gift, but he wisely creates an opportunity within the church that requires a church member to assist with teaching. The church member, led by the Spirit, accepts the opportunity and with dependence on God (perhaps even with much trembling like Paul in 1 Corintheans 2:3) begins to teach in this ministry. It may be only then - through this ministry opportunity - the church member begins to realise the spiritual giftedness of teaching, which the Spirit is demonstrating through him.

Fourthly, church leaders should allow for the orderly decentralisation and diversification of spiritually-gifted ministries. Creating ministry opportunities is the responsibility of church leaders, ${ }^{29}$ but they should not try to control the giftedness use and ministry of all believers. While all believers must always recognise and submit to the leadership authorities that Christ has appointed in his church, it is very likely and certainly not problematic that they, being led by the Spirit, become involved in many spiritual ministries. So like Barnabas church leaders should encourage these ministries to remain faithful to the Lord and his purpose for giftedness use, namely the spiritual growth and maturity of the multi-ethnic body of Christ (Ac 11:23). In this way the Holy Spirit will use the spiritual giftedness of believers to produce genuine church growth.

\section{Acknowledgements Competing interests}

The author declares that he has no financial or personal relationships which may have inappropriately influenced him in writing this article.

\section{References}

Anderson, J.C., 2000, 'Church development', in A. Scott Moreau (ed.), Evangelical Dictionary of World Missions, pp. 196-197, Baker Books, Grand Rapids, MI.

Berding, K., 2000, 'Confusing word and concept in "Spiritual gifts": Have we forgotten James Barr's exhortations?', Journal of the Evangelical Theological Society 43(1), 37-51.

Bridge, D. \& Phypers, D., 2002, Spiritual gifts and the church, 2nd edn., Christian Focus, Ross-shire.

Carson, D.A., 1987, Showing the Spirit, Baker Books, Grand Rapids, MI.

Deere, J., 1993, Surprised by the power of the Spirit, Zondervan, Grand Rapids, MI.

DeVries, B.A., 2007, 'Witnessing with the Holy Spirit: Pneumatology and missiology in evangelistic theory', Southern Seminary, 138-149.

Fee, G.D., 1994, God's empowering presence: The Holy Spirit in the letters of Paul, Hendrickson, Peabody, MA.

Gaffin, R.B. Jr., 1979, Perspectives on Pentecost: New Testament teaching on the gifts of the Holy Spirit, Baker Books, Grand Rapids, MI.

Goodwin, T., 1979, The work of the Holy Spirit, Banner of Truth Trust, Carlisle, MA.

Grudem, W., 1994, Systematic theology: An introduction to biblical doctrine, Zondervan, Grand Rapids, MI.

Grudem, W. (ed.), 1996, Are miraculous gifts for today? Four views, Zondervan, Grand Rapids, MI.

Grudem, W., 2000, The gift of prophecy in the New Testament and today, Crossway, Wheaton, IL.

Isichei, E., 1995, A history of Christianity in Africa, Eerdmans, Grand Rapids, MI.

Köstenberger, A.J., 1997, 'What does it mean to be filled with the Spirit? A biblical investigation', Journal of the Evangelical Theological Society 40, 229-240.

29. Church leaders sometimes fail to create ministry opportunities for all believers and instead try to do all the work themselves. It is not uncommon in such cases for the instead try to do all the work themselves. It is not uncommon in such cases for the
church members themselves to start their own ministries, either within the church or outside the immediate context of the church. 
Marcel, P.C., 1963, The relevance of preaching, transl. Rob R. McGregor, Baker Books, Grand Rapids, MI.

Miller, C.J., 1986, Outgrowing the ingrown church, Zondervan, Grand Rapids, MI.

Moltmann, J., 1993, The church in the power of the Spirit, Fortress, Minneapolis.

Owen, J., 2004, The Holy Spirit: His gifts and power, Christian Focus, Ross-shire.

Packer, J.I., 1990, 'John Owen on spiritual gifts', in J.I. Packer (ed.), A quest for godliness: The puritan vision of the Christian life, pp. 219-230, Crossway Books, Wheaton, IL.

Packer, J.I., 2005, Keep in step with the Spirit: Finding fullness in our walk with God, rev. edn., Baker Books, Grand Rapids, MI.

Perkins, W., 1996, The art of prophesying, Banner of Truth, Carlisle, MA.

Pinnock, C.H., 1996, Flame of love: A theology of the Holy Spirit, InterVarsity, Downers Grove, IL.

Piper, J. \& Grudem, W. (eds.), 1991, Recovering biblical manhood \& womanhood, Crossway Books, Wheaton, IL.

Poythress, V.S., 1996, 'Modern spiritual gifts as analogous to apostolic gifts: Affirming extraordinary works of the Spirit within cessationist theology', Journal of the Evangelical Theological Society 39(1), 71-101.

Poythress, V.S., 2010, What are spiritual gifts? P\&R Publishing, Phillipsburg.
Pytches, D., 1987, Spiritual gifts in the local church, Bethany House, Minneapolis.

Reeder III, H.L. \& Swavely, D., 2004, From embers to a flame: How God can revitalize your church, P \& R Publishing, Phillipsburg.

Ross, M., 2006, Preaching for revitalization: How to revitalize your church through your pulpit, Mentor, Ross-shire.

Satyavrata, I., 2000, 'Gifts of the Spirit', in A. Scott Moreau (ed.), Evangelical dictionary of world missions, pp. 391-393, Baker Books, Grand Rapids, MI.

Shaw, M., 1996, The kingdom of God in Africa, Baker Books, Grand Rapids, MI.

Smith, D.R., 2001, 'The Scottish Presbyterians and Covenanters: A continuationist experience in a cessationist theology', Westminster Theological Journal 63(1), 39-63.

Snyder, H., 1989, Signs of the Spirit: How God reshapes the church, Zondervan, Grand Rapids, MI.

Vaughan, C.R., 1975, The gifts of the Holy Spirit: To unbelievers and believers, Banner of Truth Trust, Carlisle, MA.

Wagner, C.P., 1979, Your spiritual gifts can help your church grow, Regal, Ventura.

Yong, A., 2005, The Spirit poured out on all flesh: Pentecostalism and the possibility of global theology, Baker Academic, Grand Rapids, MI. 